\title{
PENGARUH EFEKTIVITAS PENERAPAN $e$-FILING DAN MODERNISASI SISTEM PERPAJAKAN INDONESIA TERHADAP EFEKTIVITAS PEMROSESAN DATA PERPAJAKAN
}

\author{
Yohanes Mardinata Rusli \\ Universitas Bunda Mulia \\ yrusli@bundamulia.ac.id
}

\begin{abstract}
The tax e-filing system is a method of reporting tax returns that are carried out electronically or online through the Directorate General of Tax's website (DGT Online), or through other official e-Filing channels that have been determined by the government through laws and government regulations. the existence of an e-filing system online system then you do not spend the time necessary to come to the tax office to wait in the process of tax payment This study aims to determine the effect of the effectiveness of the implementation of tax e-filing and the modernization of the Indonesian tax system on the effectiveness of tax data processing for individual taxpayers in area of the Bunda Mulia University. This study uses quantitative analytical research methods, where data is obtained through the distribution of questionnaires to individual taxpayers in the Bunda Mulia educational foundation environment in Jakarta. The amount of respondents who used a total of 120 respondents. The questionnaire data obtained was processed using Statistical Product and Service Solutions (SPSS) software version 24. The results of this study indicate: (i) The effectiveness of the application of e-filing systems carried out by DGT assessed by taxpayers has a significant positive effect on the effectiveness of tax data processing. (ii) The modernization of the Indonesian Tax System that is consistently carried out by the DGT in the eyes of a taxpayer's perception has a significant positive effect on the effectiveness of tax data processing. This research contributes to assist and support the implementation of e-filing systems organized by the Ministry of Finance of the Republic of Indonesia, especially the Directorate General of Taxes (DGT). In addition, the use of information technology in taxation is expected to improve services to taxpayers, both from quality and time so that it is more effective.
\end{abstract}

Keyword : e-filing system, modernization of taxation system, taxation data processing, Indonesian taxation.

\begin{abstract}
ABSTRAK: Sistem e-filing pajak merupakan cara pelaporan Surat Pemberitahuan (SPT) pajak yang dilakukan secara elektronik atau online melalui website Direktorat Jenderal Pajak (DJP Online), maupun melalui saluran e-Filing resmi lainnya yang sudah ditetapkan oleh pemerintah melaui undang-undang maupun peraturan pemerintah. Dengan sistem e-filing ini sudah menganut sistem online, maka anda tidak perlu repot lagi datang ke kantor pajak untuk mengantre dalam proses pembayaran pajak. Penelitian ini bertujuan untuk mengetahui pengaruh antara efektivitas penerapan e-filing perpajakan dan modernisasi sistem perpajakan Indonesia terhadap efektivitas pemrosesan data perpajakan bagi wajib pajak orang pribadi di lingkungan yayasan pendidikan Bunda Mulia. Penelitian ini menggunakan metode penelitian analitis kuantitatif, dimana data diperoleh melalui penyebaran kuisioner kepada wajib pajak orang pribadi pada lingkungan yayasan pendidikan Bunda Mulia di Jakarta. Jumlah responden yang digunakan sebanyak 120 responden. Data kuesioner yang diperoleh tersebut diolah dengan dengan menggunakan software Statistical Product and Service Solutions (SPSS) versi 24. Hasil penelitian ini menunjukkan adanya: (i) Efektivitas penerapan sistem $e$-filing yang dijalankan oleh pihak DJP yang dinilai oleh Wajib Pajak yang bekerja di Yayasan Bunda Mulia di dalam menjalankan kewajiban perpajakannya berpengaruh positif secara signifikan terhadap efektivitas pemrosesan data perpajakan. (ii) Modernisasi Sistem Perpajakan Indonesia yang dijalankan dengan konsisten oleh Pihak DJP dimata persepsi seorang Wajib Pajak berpengaruh positif secara signifikan terhadap efektivitas pemrosesan data perpajakan. Penelitian ini memiliki kontribusi di dalam membantu dan mendukung program penyelenggaraan sistem e-filing yang diselenggarakan oleh Kementerian Keuangan Republik Indonesia, khusunya Direktorat Jenderal Pajak (DJP). Selain itu, penggunaan teknologi informasi dalam perpajakan diharapkan meningkatkan pelayanan terhadap Wajib Pajak, baik dari kualitas maupun waktu sehingga lebih efektif.
\end{abstract}


Kata Kunci: sistem e-filing, modernisasi sistem perpajakan, pemrosesan data perpajakan, perpajakan Indoneia.

\section{Pendahuluan}

Penerimaan pajak memiliki peran yang besar untuk meningkatkan aset negara, sehingga Direktorat Jenderal Pajak melakukan peningkatan penerimaan dalam sektor pajak (Pratami \& Wahyuni, 2017). Secara umum pajak adalah iuran rakyat kepada kas negara berdasarkan Undang-Undang sehingga dapat dipaksakan pernyataan tersebut tencamtum dalam UU No. 28 Th 2007. Pajak merupakan pendapatan utama negara untuk membiayai segala macam kebutuhan, berperan untuk mensejahterakan masyarakat di Indonesia. Pajak merupakan sumber pendapatan bagi pemerintah untuk dipastikan ekonomi berkelanjutan di dalam negeri (Ersania \& merkusiwati, 2018). Pertumbuhan negara akan meningkat apabila masyarakat sebagai Wajib Pajak memenuhi kewajibannya dalam pembayaran pajak. Perkembangan teknologi saat ini sangat pesat, hal ini juga membuat Direktorat Jenderal Pajak (DJP) sebagai lembaga yang mempunyai kewenangan mengenai hal perpajakan di Indonesia mengikuti perkembangan teknologi tersebut dalam penerapan sistem pemungutan perpajakan yang berlaku di Indonesia saat ini, yaitu self assesment system yang merupakan system pemungutan pajak dimana Wajib Pajak diberikan kepercayaan untuk menghitung, mambayar, dan melaporakan kewajiban perpajakannya sendiri, bukan oleh pihak laian maupun pihak pemerintah Penerapan kemajuan teknologi ini diterapkan dapam system administrasi perpajakan modern dengan pelayanan perpajakan yang berbasis pada e-system, seperti: e-registration, e-SPT, e-faktur, e-filing, dan e-billing.

E-Sytem memberikan fasilitas bagi Wajib Pajak untuk melakukan kewajiban pajaknya secara online ataupun secara elektronik, sehingga diharapkan memberikan kemudahan baik dalam pendaftaran ataupun pelaporan Surat Pemberitahuan (SPT) (Melli dan Rizal 2009). Pelaporan SPT pajak tahunan Wajib Pajak Orang Pribadi (WP OP) yang mempunyai batas waktu sampai tanggal 31 Maret tahun berikutnya membuat tax officer, dalam hal ini Direktorat Jenderal Pajak yang diwakili oleh kantor-kantor pelayanan pajak (KPP) yang ada mengalami peningkatan pelayanan. Hal ini kita temukan di beberapa kantor-kantor pelayanan pajak yang ada selalu ramai dan mengantri untuk melaporkan SPT pajak tahunan. Hal ini membuat Wajib Pajak Orang Pribadi (WP OP) tidak berminat untuk melakukan pelaporan Surat Pemberitahuan (SPT) sehingga membuat Wajib Pajak Orang Pribadi (WP OP) tidak menjalankan kewajiban perpajakannya yaitu melaporkan pajak nya.

E-Registration atau sistem online pendaftaran Wajib Pajak merupakan bagian dari suatu sistem informasi perpajakan yang dirancang oleh Direktorat Jenderal Pajak (DJP) sebagai sistem berbasis aplikasi dengan menggunakan perangkat keras maupun perangkat lunak yang dihubungkan oleh perangkat komunikasi data. $E$ Registration ini dapat digunakan dalam mengelola proses pendaftaran wajib pajak. Secara singkat E-Registration diartikan sebagai sistem pendaftaran, perubahan data wajib pajak dan atau pengukuhan dan pencabutan pengukuhan pengusaha kena pajak yang dihubungkan dengan Direktorat Jenderal Pajak (DJP) secara langsung atau online. Sistem ini terdiri dari dua bagian, yaitu sistem online yang berfungsi sebagai media pendaftaran wajib pajak yang digunakan oleh wajib pajak, dan sistem online yang berfungsi sebagai media memproses 
pendaftaran wajib pajak yang digunakan oleh petugas pajak.

Sistem Administrasi perpajakan yang diterapkan oleh pihak otoritas perpajakan di Indonesia dalam hal ini DJP, seiring dengan perkembangan kemajuan teknologi dan hambatan yang membuat Wajib Pajak Orang Pribadi (WP OP) dalam melaporkan perpajakannya, maka DJP mempermudah WP OP dalam melaporkan perpajakannya dengan berbasis e-system, yaitu dengan e-filing. Tujuan dengan efiling system ini untuk mempermudah wajib pajak untuk melaporkan SPT pajak tahunannya, meningkatkan jumlah wajib pajak yang patuh, dan mengefisienkan system pelaporan pajak yang berlaku saat ini.

E-filing system sudah diterapkan di Indonesia sejak tahun 2005 mengalami pertumbuhan wajib pajak yang berminat dalam melaporkan kewajiban perpajakannya dengan system ini. Namun masih belum signifikan pertumbuhan jumlah Wajib Pajak Orang Pribadi (WP OP) yang melaksanakan pelaporan Surat Pemberitahuan (SPT) tahunan pajaknya secara e-filing. Berdasarkan beberapa paparan menganai fakta di lapangan dan penelitian sebelumnya mengenai $e$-filing system perpajakan yang penulis dapatkan, maka penulis tertarik untuk melakukan penelitian mengenai Pengaruh Minat Wajib Pajak dan Efektivitas Sistem efiling terhadap sistem perpajakan yang berlaku di Indonesia saat ini, yaitu sistem self-assessment.

Kurangnya pemahaman Wajib Pajak pada sistem e-filing yang diterapkan oleh pihak pemerintah, khususnya Kementrian Keuangan Republik Indonesia - Direktorat Jenderal Pajak (DJP) akan menyebabkan masih banyaknya Wajib Pajak yang tidak mau menggunakan sistem e-filing dan lebih baik menggunakan pelapora perpajakannya dengan mengisi dan mengirimkan SPT tahunan nya secara manual sehingga terjadi penumpukan dokumen yang harus diarsipkan oleh kantor pajak.

Persepsi para Wajib Pajak terhadap penerapan sistem e-filing yang dipergunakan dalam sistem administrasi perpajakan penting untuk diketahui, karena secara tidak langsung dapat berkaitan dengan kepercayaan dan dukungan masyarakat terhadap niat baik pemerintah dalam menyelenggarakan sistem administrasi perpajakan yang transparan, jujur, dan adil. Jika persepsi Wajib Pajak Orang Pribadi (WP OP). mengenai penerapan sistem e-filing dianggap telah membantu dalam pemerosesan data dan efisiensi untuk penyimpanan dokumen pelaporan pajak, maka dapat dikatakan bahwa penerapan $e$-filing berpengaruh terhadap efisiensi pemrosesan data perpajakan di dalam sistem perpajakan yang berlaku di Indonesai saat ini.

Penting untuk mengetahui persepsi para Wajib Pajak mengenai penerapan sistem e-filing karena berkaitan dengan niat dari pemerintah dimana dalam hal ini dibawah kementerian keuangan yaitu: Direktorat Jendral Pajak (DJP) untuk menghimpun penerimaan pajak melalui reformasi dibidang perpajakan (modernisasi sistem administrasi perpajakan). Apabila persepsi Wajib Pajak mengenai penerapan e-filing selama ini dianggap telah membantu dalam pemrosesan data perpajakan maka dapat dikatakan bahwa penerapan sistem e-filing berpengaruh terhadap efisiensi pemrosesan data perpajakan bagi Wajib Pajak Orang Pribadi (WP OP) yang menjadi sampel pada penelitian ini.

Berdasarkan latar belakang tersebut dapat disusun rumusan masalah sebagai berikut Apakah sistem modernisasi perpajakan yang sudah beberpa tahun belakangan ini, sejak tahun 2010 digalakkan dapat 
mempengaruhi efektivitas pemrosesan data perpajakan yang dilakukan oleh Wajib Pajak, khusunya Wajib Pajak Orang Pribadi pada penelitian ini ?

Penelitian ini bertujuan untuk mengetahui pengaruh antara efektivitas penerapan sistem $e$-filing perpajakan dan modernisasi sistem perpajakan Indonesia terhadap efektivitas pemrosesan data perpajakan bagi wajib pajak orang pribadi di lingkungan yayasan pendidikan Bunda Mulia. Manfaat dari penelitian ini adalah sebagai berikut: (a) Bagi penulis, hasil penelitian ini berguna untuk dapat mengetahui efektivitas penerapan sistem e-filing terhadap efektivitas pemrosesan data perpajakan; (b) Penelitian ini diharapkan dapat memberikan kontribusi untuk masyarakat pada umumnya dan Direktorat Jenderal Pajak (DJP) pada khususnya untuk mengetahui seberapa efektif dan seberapa besar minat penerapan e-filing dan pelaksanaan self-assessment system yang berlaku di Indonesia terhadap efektivitas pemrosesan data perpajakan; (c) Bagi peneliti selanjutnya, hasil penelitian ini berguna sebagai bahan informasi dan kajian untuk penelitian selanjutnya pada bidang perpajakan.

\section{Theory of Planned Behavior (TPB)}

Theory of Planned Behavior (TPB) mendeskripsikan bahwa perilaku yang ditampilkan oleh individu timbul karena adanya niat untuk berperilaku. Sedangkan muncul niat berperilaku ditentukan oleh 3 faktor, yaitu: (1) behavioral beliefs, yaitu keyakinan individu akan hasil dari suatu perilaku dan evaluasi atas hasil tersebut (beliefs strength and outcome evaluation), (2) normatif beliefs, yaitu keyakinan tentang harapan normatif orang lain dan motivasi untuk memenuhi harapan tersebut (normatif beliefs and motivation to comply), dan (3) control beliefs, yaitu keyakinan tentang keberadaan hal-hal yang mendukung atau menghambat perilaku yang akan ditampilkan (control beliefs) dan persepsinya tentang seberapa kuat hal-hal yang mendukung dan menghambat perilaku tersebut (perceived power).

Hambatan yang mungkin timbul pada saat perilaku ditampilkan dapat berasal dari dalam diri sendiri maupun dari lingkungan. Secara berurutan, behavioral beliefs menghasilkan sikap terhadap perilaku positif atau negatif, normative beliefs menghasilkan tekanan sosial yang dipersepsikan (perceived social pressure) atau norma subyektif (subjective norm) dan control beliefs menimbulkan perceived behavioral control atau kontrol keperilakuan yang dipersepsikan (Ajzen, 2002)

\section{Kajian Pustaka}

\section{Gambar 1}

\section{Theorv of Planned Behavior}

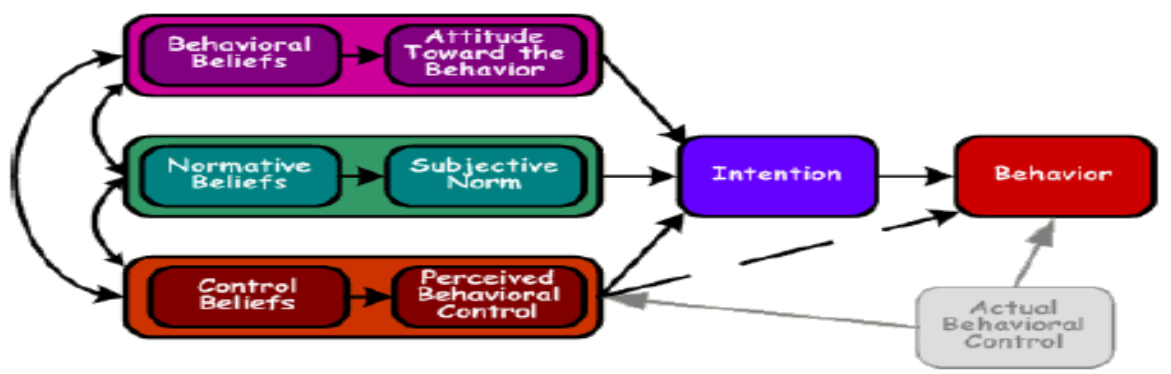

Sumber: Ajzen, I. (1991). The theory of planned behavior. Organizational Behavior and Human Decision Processes, 50, p. 179-211 


\section{E-System}

E-System dalam perpajakan adalah suatu bentuk modernisasi perpajakan yang memanfaatkan sistem komunikasi dan teknologi internet (Melli \& Rizal 2009). e-System memiliki aplikasinya yang meliputi e-Registration (pendaftaran wajib pajak melalui internet), e-Filing (pelaporan pajak melalui internet), e-SPT (pengisian SPT dengan program yang disediakan DJP), e-Faktur (faktur pajak elektronik) dan eBilling (pembayaran elektronik). esystem merupakan sistem elektronis yang memberikan informasi mengenai beban pajak (kewajiban) pembayaran pajak setiap orang atau badan yang terdaftar di kantor pajak. Berikut adalah jenis-jenis esystem yang diupayakan oleh Direktorat Jenderal Pajak:

1) e-Registration

Sistem pendaftaran Wajib Pajak untuk memperoleh Nomor Pokok Wajib Pajak (NPWP) secara online.

2) $e-S P T$

Program aplikasi yang merupakan sarana bagi Wajib Pajak untuk dapat

\section{Modernisasi Sistem Perpajakan Indonesia}

Sejak tahun 2002, Direktorat Jenderal Pajak (DJP) telah meluncurkan program perubahan (change program) atau reformasi administrasi perpajakan yang secara umum oleh kalangan Direkrorat Jenderal Pajak disebut Modernisasi Sistem Perpajakan Indonesia. Adapun jiwa dari program modernisasi ini adalah pelaksanaan good governance, yaitu penerapan sistem administrasi perpajakan yang transparan dan akuntabel, dengan memanfaatkan sistem informasi teknologi yang handal dan terkini (Fasmi, L. dan Misra, F. 2012).

Konsep modernisasi administrasi perpajakan pada prinsipnya adalah merupakan perubahan pada sistem menyampaikan Surat Pemberitahuan (SPT) melalui media elektronik.

Manfaat dari penelitian ini adalah sebagai berikut: (a) Bagi penulis, hasil penelitian ini berguna untuk dapat mengetahui efektivitas penerapan sistem e-filing terhadap efektivitas pemrosesan data perpajakan; (b) Penelitian ini diharapkan dapat memberikan kontribusi untuk masyarakat pada umumnya dan Direktorat Jenderal Pajak (DJP) pada khususnya untuk mengetahui seberapa efektif dan seberapa besar minat penerapan e-filing dan pelaksanaan selfassessment system yang berlaku di Indonesia terhadap efektivitas pemrosesan data perpajakan; (c) Bagi peneliti selanjutnya, hasil penelitian ini berguna sebagai bahan informasi dan kajian untuk penelitian selanjutnya pada bidang perpajakan.

Administrasi perpajakan yang dapat mengubah pola pikir dan perilaku aparat serta tata nilai organisasi sehingga dapat menjadikan Direktorat Jenderal Pajak (DJP) menjadi suatu institusi yang profesional dengan citra yang baik di masyarakat.

\section{Sistem Pemungutan Pajak}

Menurut Waluyo (2016), sistem pemungutan pajak dapat dibagi menjadi tiga sistem yaitu:

1) Official Assessment system

Sistem ini merupakan sistem pemungutan pajak yang memberi wewenang kepada pemerintah (fiskus) untuk menentukan besarnya pajak terutang. Ciri-ciri official assessment system: a) Wewenang untuk menentukan besarnya pajak terutang 
berada pada fiskus; b) Wajib Pajak bersifat pasif; c) Utang pajak timbul setelah dikeluarkannya surat ketetapan pajak oleh fiskus.

2) Self Assessment System

Sistem ini merupakan sistem pemungutan pajak yang memberi wewenang, kepercayaan, tanggung jawab kepada Wajib Pajak untuk menghitung, membayar, dan melaporkan sendiri besarnya pajak yang harus dibayar.

3) Withholding System

Sistem ini merupakan sistem pemungutan pajak yang memberi wewenang kepada pihak ketiga untuk memotong atau memungut besarnya pajak yang terutang oleh Wajib Pajak.

\section{Self Assessment System}

Menurut Resmi (2011:10) Self

Assessment System adalah: "Self Assessment System adalah sistem pemungutan pajak yang memberi wewenang Wajib Pajak dalam menentukan sendiri jumlah pajak yang terutang setiap tahunnya sesuai dengan peraturan perundang-undangan perpajakan yang berlaku."

Sedangkan menurut Waluyo (2011:16) self-assessment system memiliki pengertian: "Self-Assessment System" adalah sistem pemungutan pajak yang memberi wewenang, kepercayaan, tanggung jawab kepada Wajib Pajak untuk menghitung, membayar, dan melaporkan sendiri besarnya pajak yang harus dibayar."

Dalam sistem ini, inisiatif serta kegiatan menghitung dan memungut pajak sepenuhnya berada di tangan Wajib Pajak. Wajib Pajak dianggap mampu menghitung pajak, mampu memahami undang-undang perpajakan yang sedang berlaku, dan mempunyai kejujuran yang tinggi, serta menyadari akan arti pentingnya membayar pajak. Oleh karena itu, dalam Siti Resmi (2011:11), Wajib Pajak diberi kepercayaan untuk: 1) Menghitung sendiri pajak yang terutang; 2)
Memperhitungkan sendiri pajak yang terutang; 3) Membayar sendiri jumlah pajak yang terutang; 4) Melaporkan sendiri jumlah pajak yang terutang; 5) Mempertanggungjawabkan pajak yang terutang.

\section{Pengembangan Hipotesis}

Penelitian terhadap efisiensi pemrosesan data perpajakan dapat menggunakan indikator perilaku Wajib Pajak berdasarkan kerangka model teori Technology Acceptance Model (TAM) yang menjelaskan perilaku penerimaan Wajib Pajak terhadap suatu teknologi informasi yang diterapkan oleh Direktorat Jenderal Pajak (DJP) dengan e-filing system. Menurut Asriningsih \& Noviari (2014), penerapan sistem e-filing dapat mempengaruhi efektivitas pemrosesan data perpajakan wajib pajak. Dengan kata lain, seseorang akan puas menggunakan sistem jika mereka meyakini bahwa sistem tersebut mudah digunakan dan mampu meningkatkan produktivitas, yang tercermin dari kondisi nyata penggunaan. Penelitian lain yang mendukung hipotesis ini adalah penelitian Lingga (2012), bahwa penerapan e-SPT berpengaruhi secara significant terhadap efisiensi pemrosesan data Perpajakan, dimana penerapan eSPT merupakah salah satu dari e-filing system.

$\mathrm{H}_{1}$ : Efektivitas penerapan sistem e-filing berpengaruh signifikan positif terhadap efektivitas pemrosesan data perpajakan wajib pajak.

Menurut penelitian Ivana \&Sadjiarto (2013), secara tidak langsung penggunaan $e$-SPT ini membantu wajib pajak memenuhi kewajiban perpajakan dan dapat mengefisiensikan pemrosesan data perpajakan bagi Wajib Pajak yang melakukan transaksi cukup besar, 
sehingga kepatuhan Wajib Pajak diharapkan akan meningkat.

Salah satu langkah pemerintah dalam hal ini Direktorat Jenderal Pajak (DJP) modernisasi sistem administrasi perpajakan yang dilakukan oleh Direktorat Jendral Pajak sebagai bentuk untuk meningkatkan kualitas pelayanan perpajakan adalah dengan mengembangkan pelaporan pajak terutang menggunakan elektronik SPT (e-SPT). Penggunaan elektronik SPT dimaksudkan untuk memudahkan dalam penyampaian SPT, karena dinilai bahwa pelaporan pajak terutang melalui SPT manual masih memiliki kelemahan khususnya bagi wajib pajak yang melakukan transaksi cukup besar harus melampirkan dokumen (hardcopy) dalam jumlah cukup besar kepada Kantor Pelayanan Pajak (KPP), sementara proses perekaman data memakan waktu cukup lama sehingga pelaporan SPT menjadi tertunda dan terlambat (Asriningsih dan Noviari, 2014).

$\mathrm{H}_{2}$ : Modernisasi Sistem Perpajakan Indonesia berpengaruh signifikan positif terhadap efektivitas pemrosesan data perpajakan wajib pajak.

\section{Metode Penelitian \\ Rancangan Penelitian dan Model Penelitian}

Dalam penelitian ini yang menjadi subjek penelitian adalah para Wajib Pajak Orang Probadi (WPOP) yang bekerja pada Yayasan Bunda Mulia di wilyah Jakarta pada tahun 2017.

Objek penelitian dalam penelitian ini adalah efektivitas penerapan sistem efiling dan modernisasi sistem perpajakan Indonesia "self-assessment system" sebagai variabel independen, serta sistem pemrosesan data perpajakan sebagai

\section{Pengembangan Instrumen}

variabel dependen. Objek penelitian ini dipilih oleh peneliti dikarenakan sesuai Aanggaran Penerimaan dan Belanja Negara (APBN) yang menjadikan pajak sebagai tulang punggung penerimaan negara guna membiayai pembangunan negeri ini dan penerimaan dari sektor pajak diharapkan terus meningkat dari tahun ke tahun. Selain itu, sistem perpajakan Indonesia yang sudah berjalan sejak tahun 1983 (lebih dari tiga dekade) yaitu "self -assessment" dan sistem e-filing yang merupakan sebuah produk inovasi perkembangan teknologi informasi yang disediakan untuk memudahkan sekaligus meningkatkan pelayanan kepada para pembayar pajak dalam melaksanakan hak dan memenuhi kewajiban perpajakannya.

Penelitian ini menggunakan metode kuantitatif dengan menggunakan jenis penelitian yang dilakukan dengan pendekatan dan data bersifat kuantitatif. Menurut Sujarweni (2014) penelitian kuantitatif adalah jenis penelitian yang menghasilkan penemuan-penemuan yang dapat dicapai dengan menggunakan prosedur-prosedur statistik. Sedangkan jenis penelitian yang digunakan dalam penelitian ini adalah penelitian kausal komparatif yang termasuk dalam bagian asosiatif atau hubungan.

Menurut Sujarweni (2014) penelitian asosiatif bertujuan untuk mengetahui hubungan antar dua variabel atau lebih serta mengetahui pengaruhnya. Sementara menurut Hartono (2013) hipotesis asosiatif atau hubungan dapat diklasifikasikan kembali menjadi hipotesis korelasi dan hipotesis kausal. Hipotesis kausal adalah hipotesis yang menyebabkan perubahan variabel yang lainnya. Suryabrata (2014) menyatakan tujuan penelitian kausal-komparatif adalah untuk menyelidiki kemungkinan hubungan sebab-akibat dengan cara berdasar atas pengamatan terhadap akibat yang mencari kembali faktor yang mungkin menjadi penyebab melalui data tertentu. 
Tabel 1

Operasionalisasi Variabel

\begin{tabular}{|c|c|c|}
\hline VARIABEL & INDIKATOR & $\begin{array}{c}\text { SKALA } \\
\text { PENGUKURAN }\end{array}$ \\
\hline $\begin{array}{l}\text { Efektivitas Penerapan } \\
\text { Sistem } \text { e-filing (X1) } \\
\text { Wibisona, L.T dan Toly, } \\
\text { A. A. (2014); } \\
\text { Lingga, I. S. (2012) }\end{array}$ & $\begin{array}{ll}\text { 1. } & \text { Kepraktisan aplikasi } e \text {-filing } \\
\text { 2. Kemudahan pemakaian aplikasi } \\
\text { e-filing } \\
\text { 3. Keamanan aplikasi } e \text {-filing }\end{array}$ & Interval \\
\hline $\begin{array}{l}\text { Modernisasi Sistem } \\
\text { Perpajakan Indonesia } \\
\text { (X2) } \\
\text { Fasmi, L. dan Misra, F. } \\
(2012)\end{array}$ & $\begin{array}{ll}\text { 1. } & \text { Modernisasi Struktur Organisasi } \\
\text { 2. } & \text { Modernisasi Prosedur Organisasi } \\
\text { 3. } & \text { Modernisasi Strategi Organisasi } \\
\text { 4. } & \text { Modernisasi Budaya Organisasi }\end{array}$ & Interval \\
\hline $\begin{array}{l}\text { Efektivitas Pemrosesan } \\
\text { Data Perpajakan (Y) } \\
\text { Lingga, I. S. (2012) }\end{array}$ & $\begin{array}{l}\text { 1. Menghasilkan informasi yang } \\
\text { jelas, akurat dan tepat waktu.. } \\
\text { 2. Menghemat waktu } \\
\text { 3. Menghemat biaya. }\end{array}$ & Interval \\
\hline
\end{tabular}

Sumber: Data diolah penulis (2018)

Tahapan Analisis Pengolahan Data

Pada penelitian ini, penulis menggunakan data primer yang berasal dari lapangan. Agar data yang diperoleh tersebut dapat dipergunakan maka data tersebut harus diolah terlebih dahulu. Pada tahapan pengolahan data, penulis akan melakukan:

a. Penyebaran Kuesioner ke Responden Utama

Penulis melakukan penyebaran kuesioner langsung ke responden utama dari penelitian ini. Penyebaran kuesioner dilakukan pada karyawan (staff dan dosen/guru) Universitas Bunda Mulia dan Sekolah Bunda Mulia.

b. Tabulasi

Setelah data dari responden utama kembali, data tersebut dibuat daftar skornya berdasarkan seluruh jawaban atas pernyataan dari responden, maka data tersebut ditabulasikan. Tabulasi adalah suatu bentuk penyajian hasil penelitian dalam bentuk numerik dan grafik.

\section{Hasil dan Pembahasan \\ Penyajian Data Deskripsi Responden}

Penelitian ini dilakukan dengan menyebarkan kuesioner kepada Wajib Pajak Orang Pribadi (WP OP) yang bekerja pada Yayasan Bunda Mulia di wilayah DKI Jakarta dan melakukan kewajiban perpajakannya. Penelitian ini menggunakan sampel sebanyak 120 orang Wajib Pajak Orang Pribadi sebagai responden. 
Tabel 2

Statistika Kuesioner

\begin{tabular}{|l|c|c|}
\hline \multicolumn{1}{|c|}{ Keterangan } & Jumlah & Persentase \\
\hline Kuesioner yang disebarkan & 120 & $100 \%$ \\
\hline Kuesioner yang tidak kembali & 10 & $8,33 \%$ \\
\hline Kuesioner yang tidak dapat diolah & 8 & $6,67 \%$ \\
\hline Kuesioner yang diolah & 102 & $85,00 \%$ \\
\hline
\end{tabular}

Sumber: data primer yang diolah peneliti (2018)

Dalam penyebaran kuesioner ini, proses pemilihan sampel dengan metode sebanyak 120 kuesioner disebarkan, purposive sampling sehingga didapati namun ada sebanyak 10 kuesioner yang bahwa ada sebanyak 8 kuesioner yang tidak dikembalikan. Setelah semua tidak dapat diolah dan sebanyak 102 kuesioner terkumpul, maka dilakukan kuesioner yang dapat diolah.

\section{Deskripsi Profil Responden}

Tabel 3

Profil Responden

\begin{tabular}{|c|c|c|}
\hline & Jumlah Responden & Persentase $(\%)$ \\
\hline \multicolumn{3}{|c|}{ Jenis Kelamin: } \\
\hline Laki-laki & 74 & 72,55 \\
\hline Perempuan & 28 & 27,45 \\
\hline Total & 102 & 100 \\
\hline \multicolumn{3}{|c|}{ Pendidikan: } \\
\hline SMP & 1 & 0,98 \\
\hline SMA & 21 & 20,59 \\
\hline S1 & 58 & 56,86 \\
\hline S2 & 20 & 19,61 \\
\hline S3 & 2 & 1,96 \\
\hline Total & 102 & 100 \\
\hline \multicolumn{3}{|c|}{ Pengalaman Kerja: } \\
\hline $1 \mathrm{~s} / \mathrm{d} 3$ tahun & 31 & $30,39 \%$ \\
\hline $4 \mathrm{~s} / \mathrm{d} 5$ tahun & 46 & $45,10 \%$ \\
\hline$>5$ tahun & 25 & $24,51 \%$ \\
\hline Total & 102 & 100 \\
\hline \multicolumn{3}{|c|}{ Penghasilan Kotor: } \\
\hline Rp 4.500.001 s/d 7.000.000,- & 64 & 62,75 \\
\hline Rp.7.000.001 s/d Rp.10.000.000,- & 29 & 28,43 \\
\hline Rp 10.000.001 s/d Rp. 15.000.000,- & 7 & 6,86 \\
\hline$>$ Rp 15 juta & 2 & 1,96 \\
\hline Total & 102 & 100 \\
\hline
\end{tabular}

Sumber: data primer yang diolah peneliti (2018)

Tabel 3 menyajikan informasi mengenai profil responden dalam penelitian ini. Profil responden dikelompokkan berdasarkan usia, jenis kelamin, pendidikan, pengalaman kerja, serta pendapatan kotor per bulan. Hal tersebut bertujuan untuk memperjelas latar belakang responden yang berpartisipasi dalam pengisian kuesioner.

Jumlah responden laki-laki yang ikut berpartisipasi dalam pengisian kuesioner 
ada sebanyak 74 orang, dengan persentase sebesar $72,55 \%$. Sedangakan jumlah responden perempuan ada sebanyak 28 orang, dengan persentase sebesar $27,45 \%$.

Untuk tingkat pendidikan dari semua responden yang berpartisipasi dalam penelitian ini, dapat disimpulkan bahwa sebanyak 1 orang telah menempuh pendidikan SMP atau sebesar 0,98\% dari total persentase pendidikan. Sebanyak 21 orang telah menempuh pendidikan SMA dengan persentase sebesar $20,59 \%$. Sebanyak 58 orang telah menempuh pendidikan $\mathrm{S} 1$ dengan persentase sebesar $56,86 \%$, Sebanyak 20 orang telah menempuh pendidikan S2 dengan persentase sebesar $19,61 \%$, dan 2 orang yang menempuh pendidikan S3 atau sebesar $1,96 \%$ dari total persentase pendidikan.

Untuk pengalaman bekerja responden, dapat disimpulkan bahwa ada sebanyak 31 responden telah bekerja selama kurun waktu 1 s/d. 3 tahun atau sebesar 30,39\% dari seluruh persentase pengalaman kerja. Sebanyak 46 responden bekerja selama 4 s/d. 5 tahun dengan persentase sebesar $45,10 \%$, dan sebanyak 25 responden sudah bekerja selama lebih dari 5 tahun dengan persentase sebesar $24,51 \%$.

Untuk penghasilan kotor para responden, dapat disimpulkan bahwa ada sebanyak 64 responden memeiliki penghasilan sebesar Rp.4.000.000,- $\quad$ s/d. Rp.7.000.000,- atau sebesar 62,75\% dari seluruh persentase penghasilan kotor, sebanyak 29 responden berpenghasilan
Rp.7.000.001,- $\quad$ s/d. Rp.10.000.000,dengan persentase sebesar $28,43 \%$, sebanyak 7 responden memeiliki penghasilan sebesar Rp.10.000.001,- s/d. Rp.10.000.000,- atau sebesar 6,86\% dari seluruh persentase penghasilan kotor dan sebanyak 2 responden berpenghasilan lebih dari Rp. 15.000.000,- dengan persentase sebesar $1,96 \%$.

\section{Analisis Data dan Interpretasi}

Instrumen penelitian yang berpa kuesioner telah valid dan reliable serta data yang digunakan dalam penelitian ini telah lolos uji asumsi klasik sebagai syarat sebelum dilakukannya uji regresi.

\section{Uji Persamaan Regresi Linier Berganda (Hasil Uji T)}

Analisis regresi linier berganda digunakan untuk mengetahui pengaruh antara variabel independen terhadap variabel dependen, yaitu antara variabel Efektivitas Penerapan E-Filing (X1), Modernisasi Sistem Perpajakan Indonesia (X2) terhadap Efektivitas Pemrosesan Data Perpajakan (Y). Untuk mempermudah pembacaan hasil dan interpretasi regresi maka digunakan bentuk persamaan. Persamaan atau model tersebut berisi konstanta dan koefisienkoefisien regresi yang didapat dari hasil pengolahan data dengan program SPSS 24 yang disesuaikan dengan persamaan regresi. Adapun hasil uji regresi linier berganda adalah sebagai berikut:

Tabel 4

Hasil Uji Regresi Linier Berganda Hasil Uji T

\begin{tabular}{|l|l|l|l|l|}
\hline Variabel & Koefisien & T & Sig. & Keputusan \\
\hline Konstanta & 1,837 & 1,864 & 0,065 & \\
\hline Efek_Efil & 0,240 & 5,494 & 0,000 & Memiliki Pengaruh \\
\hline Mod_Pjk & 0,133 & 3,402 & 0,001 & Memiliki Pengaruh \\
\hline
\end{tabular}

Sumber: Data primer olahan SPSS 24.0 (2018) 


\begin{tabular}{|c|c|c|c|c|c|c|}
\hline \multicolumn{7}{|c|}{ Coefficients $^{a}$} \\
\hline \multirow[b]{2}{*}{ Mod } & & \multicolumn{2}{|c|}{ Unstandardized Coefficients } & \multirow{2}{*}{$\begin{array}{c}\text { Standardized } \\
\text { Coefficients } \\
\text { Beta }\end{array}$} & \multirow[b]{2}{*}{$\mathrm{t}$} & \multirow[b]{2}{*}{ Sig. } \\
\hline & & $B$ & Std. Error & & & \\
\hline \multirow[t]{3}{*}{1} & (Constant) & 1,837 & ,986 & & 1,864 &, 065 \\
\hline & Efek_Efil & ,240 & 044 &, 506 & 5,494 &, 000 \\
\hline & Mod_Pjk & ,133 & ,039 &, 313 & 3,402 & ,001 \\
\hline
\end{tabular}

a. Dependent Variable: Pros_Pjk

Berdasarkan tabel di atas hasil yang telah diperoleh dari koefisien regresi di atas, maka dapat dibuat suatu persamaan regresi sebagai berikut:

$$
\text { Pros_Pjk = 1,837 + 0,240 Efek_Efil + 0,133 Mod_Pjk + e }
$$

Dimana:

X1= Efektivitas Penerapan Sistem E-Filing (Efek_Efil)

X2= Modernisasi Sistem Perpajakan Indonesia (Mod_Pjk)

$\mathrm{Y}=$ Efektivitas Pemrosesan Data Perpajakan (Pros_Pjk)

Pada persamaan regresi di atas nilai konstanta tercantum sebesar 1,837 . Hal ini dapat diartikan jika variabel bebas dalam model persamaan yakni efektifitas penerapan sistem e-filing dan Modernisasi Perpajakan Indonesia diasumsikan konstan atau sama dengan bernilai nol (0), maka secara rata-rata variabel yang diukur model akan meningkatkan kualitas audit sebesar 1,837 satuan. Konstanta sebesar 1,837 berarti bahwa seorang wajib pajak tetap melakukan efektivitas pemrosesan data sebesar konstanta meskipun variabel lainnya berubah. Sehingga besarnya pengaruh tiap-tiap variabel independen terhadap variabel dependen adalah sebagai berikut:

a. Koefisien regresi variabel efektivitas penerapan sistem e-filing (X1) menunjukkan nilai sebesar 0,240 pada penelitian ini dapat diartikan bahwa variabel efektivitas penerapan sistem $e$-filing berpengaruh terhadap efektivitas pemrosesan data perpajakan. Hal ini menunjukkan bahwa ketika variabel $X_{1}$ mengalami peningkatan sebesar satu satuan, variabel $Y$ juga akan mengalami peningkatan sebesar 0,240 atau 24,0\% dengan catatan variabel lain dianggap konstan.

b. Koefisien regresi variabel Modernisasi Sistem Perpajakan Indonesia (X2) menunjukkan nilai sebesar 0,133 pada penelitian ini dapat diartikan bahwa variabel Modernisasi Sistem Perpajakan Indonesia berpengaruh terhadap efektivitas pemrosesan data perpajakan. Hal ini menunjukkan bahwa ketika variabel $\mathrm{X}_{2}$ mengalami penurunan sebesar satu satuan, variabel kualitas audit juga akan mengalami penurunan sebesar 0,133 atau $13,3 \%$ dengan catatan variabel lain dianggap konstan.

\section{Analisis Koefisien Determinasi}

Koefisien determinasi bertujuan untuk mengukur seberapa jauh kemampuan model dapat menjelaskan variasi variabel dependen. Dalam pengujian hipotesis ini koefisien determinasi dilihat dari seberapa besar nilai Adjusted $R$ Square $\left(R^{2}\right)$ untuk mengetahui seberapa jauh variabel bebas yaitu Efektivitas Penerapan Sistem E-Filing dan Modernisasi Sistem Perpajakan Indonesia 
terhadap Efektivitas Pemrosesan Data Perpajakan. Adapun hasil uji koefisien determinasi $\left(\mathrm{R}^{2}\right)$ adalah sebagai berikut:

\section{Hasil Uji Koefisien Determinasi}

Tabel 5 menyatakan bahwa nilai koefisien determinasi yang sudah disesuaikan (Adjusted $R$ Square) adalah 0,577 . Hal ini berarti $57,7 \%$ variasi dari penelitian efektivitas pemrosesan data perpajakan dapat dijelaskan oleh variasi variabel independen yaitu efektivitas penerapan sistem e-filing dan modernisasi sistem perpajakan Indonesia yang terdapat dalam penelitian ini. Sedangkan sisanya sebesar $42,3 \%$ dijelaskan atau dipengaruhi oleh variabel lain yang tidak ada dalam penelitan.

\section{Hasil Pengujian Hipotesis}

\section{Hasil Uji T}

Uji $\mathrm{T}$ digunakan untuk mengetahui pengaruh masing-masing variabel independen terhadap dependen yaitu antara efektivitas penerapan sistem $e$ filing dan modernisasi sistem perpajakan Indonesia terhadap efektivitas pemrosesan data perpajakan.

Tabel 5

Hasil Uji T

\begin{tabular}{|l|l|l|l|l|}
\hline Variabel & Koefisien & T & Sig. & Keputusan \\
\hline Konstanta & 1,837 & 1,864 & 0,065 & \\
\hline Efek_Efil & 0,240 & 5,494 & 0,000 & Memiliki Pengaruh \\
\hline Mod_Pjk & 0,133 & 3,402 & 0,001 & Memiliki Pengaruh \\
\hline
\end{tabular}

\begin{tabular}{|l|l|r|r|r|}
\hline \multicolumn{5}{|c|}{ Model Summary } \\
\hline Model & R & R Square & \multicolumn{1}{|c|}{$\begin{array}{c}\text { Adjusted R } \\
\text { Square }\end{array}$} & $\begin{array}{c}\text { Std. Error of } \\
\text { the Estimate }\end{array}$ \\
\hline 1 &, $760^{a}$ &, 577 &, 569 & 1,24660 \\
\hline
\end{tabular}

a. Predictors: (Constant), Mod_Pjk, Efek_Efil

Uji Hipotesis 1: Pengaruh Efektivitas Penerapan Sistem E-Filing terhadap Efektivitas Pemrosesan Data Perpajakan

Berdasarkan Tabel diatas
diperoleh nilai $\mathrm{t}$ sebesar 5,494 dan nilai signifikansi sebesar 0,000 . Nilai t tabel yang diperoleh adalah sebesar 1,98793 dengan $\mathrm{df}=102$ dan tingkat sig. 0,05. Jadi dapat disimpulkan bahwa nilai $\mathrm{t}$ hitung $>\mathrm{t}$ tabel $(5,494>1,987)$ dan nilai sig. $<0,05(0,000<0,05)$, sehingga $\mathrm{H}_{1}$ diterima, atau dengan kata lain variabel Efektivitas Penerapan Sistem E-Filing secara parsial berpengaruh terhadap variabel Efektivitas Pemrosesan Data Perpajakan.

Hasil Penelitian pada hipotesis tersebut diatas menyatakan bahwa setiap wajib pajak yang ada di Indonesia, khusunya Wajib Pajak Orang Pribadi
(WP OP) dalam menjalankan kewajiban perpajakannya sesuai dengan sistem perpajakan yang berlaku, yaitu sistem "self-assesment" salah satunya di dalam melaporkan Surat Pemberitahuan Pajak Terutang (SPT) tahunan dengan e-filling sistem telah dilakukan secara efektif sehingga dapat mempengaruhi efektivitas pemrosesan data perpajakan. Penelitian sebelumnya yang dilakukan oleh Lingga (2012), sejalan dengan penelitian ini.

\section{Uji Hipotesis 2 : Pengaruh Modernisasi Sistem Perpajakan Indonesia terhadap Efektivitas Pemrosesan Data Perpajakan}

Berdasarkan diatas, diperoleh nilai t sebesar 3,402 dan nilai signifikansi sebesar 0,001. Adapun kriteria yang digunakan dalam penelitian ini adalah jika t hitung > t tabel atau nilai sig. < 
0,05 , maka hipotesis diterima, dan jika $-\mathrm{t}$ tabel $\leq \mathrm{t}$ hitung $\leq \mathrm{t}$ tabel, maka hipotesis ditolak. Nilai $\mathrm{t}$ tabel yang diperoleh adalah sebesar 1,987 dengan $\mathrm{df}=102$ dan tingkat sig. 0,05. Jadi dapat disimpulkan bahwa nilai $\mathrm{t}$ hitung $>\mathrm{t}$ tabel $(3,402>1,987)$ dan nilai sig. $<0,05$ $(0,000<0,05)$, sehingga $\mathrm{H}_{2}$ diterima, atau dengan kata lain variabel Modernisasi Sistem Perpajakan Indonesia secara parsial berpengaruh terhadap variabel Efektivitas Pemrosesan Data Perpajakan. Modernisasi sistem Perpajakan Indonesia yang semakin diupdate dan sesuai perkembangan teknologi informasi saat ini yang dikembangakan oleh pihak Direktorat Jenderal Pajak (DJP) semakin memudahkan proses data perpajakan untuk melakukan salah satu kewajiban perpajakan sebagai Wajib Pajak yang baik dan Wajib Pajak yang patuh dengan demikian maka meningkatkan efektivitas pemrosesan data perpajakan yang dilakukan oleh Wajib Pajak Orang Pribadi, hal ini sejalan dengan penelitian yang dilakukan oleh Lingga (2012) dan Fasmi \& Misra (2013) yang menyatakan bahwa moderanisasi sistem perpajakan di Indonesia berpengaruh signifikan positif terhadap efektivitas pemrosesan data perpajakan.

\section{Interpretasi Data}

\section{Pengaruh Efektivitas Penerapan Sistem E-Filing $\left(\mathbf{X}_{1}\right)$ terhadap Efektivitas Pemrosesan Data Perpajakan (Y)}

Berdasarkan hasil analisis data penelitian yang telah diuraikan di atas, Setiap Wajib Pajak khususnya pada penelitian ini adalah Wajib Pajak Orang Pribadi (WPOP) yang bekerja pada Yayasan Bunda Mulia yang berdomisili di Jakarta di dalam menjalankan kewajiban perpajakan nya yaitu melaporkan Surat Pemberitahuan Pajak Terutang (SPT Tahunannya) dengan sistem e-filing yang dilakukan secara efektif maka akan berpengaruh positif secara signifikan terhadap pemrosesan data perpajakan yang efektif.

Semakin efektif seorang Wajib Pajak dalam melakukan kewajiban perpajkannya di dalam melaporkan SPT Pajak Tahunannya secara sistem $e$-filing, maka akan berpengaruh terhadap efektivitas pemrosesan data perpajakan, dikarenakan Sebalipemrosesan data perpajakannya akan menghemat biaya dan waktu. Hal ini sejalan dengan penelitian yang dilakukan Lie dan Sadjiarto (2013) bahwa kemudahan dan Kegunaan di dalam penerapan sistem $e$ filing membuat Wajib Pajak khusunya WPOP (Wajib Pajak Orang Pribadi) akan meningkatkan minat Wajib Pajak dalam melakukan pelaporan perpajakannya dengan sistem e-filing. Dengan demikian maka akan membuat efektivitas pemrosesan data perpajakan yang dilakukan Wajib Pajak Orang Pribadi, dikarenakan penerapan sistem e-filing yang efektif yang dijalankan oleh pihak pemerintah dalam hal ini DJP-Direktorat Jenderal Pajak Kementrian Keuangan RI, sesuai dengan penelitian Lingga (2012).

\section{Pengaruh Modernisasi Sistem Perpajakan Indonesia $\left(X_{2}\right)$ terhadap Efektivitas Pemrosesan Data Perpajakan (Y)}

Berdasarkan hasil analisis data penelitian yang telah diuraikan di atas, sistem perpajakan yang berlaku di Indonesia yang sudah dilakukan modernisasi oleh pihak Direktorat Jenderal Pajak sebagai lembaga tinggi negara yang berwenang di dalam menjalankan tanggung jawab di dalam mereformasi sistem perpajakan Indonesia.

Modernisasi administrasi perpajakan meliputi reformasi kebijakan, reformasi administrasi dan reformasi pengawasan. Reformasi kebijakan terdiri dari amandemen undang-undang antara lain UU No. 36 tahun 2008 mengenai Pajak Penghasilan, UU No. 16 tahun 2009 mengenai Ketentuan Umum dan Tata Cara Perpajakan (KUP), UU No. 42 
tahun 2009 mengenai PPN dan PPnBM. Reformasi administrasi merupakan.

Modernisasi sistem Perpajakan Indonesia yang semakin diupdate dan sesuai perkembangan teknologi informasi oleh pihak Direktorat Jenderal Pajak semakin memudahkan proses data perpajakan untuk melakukan salah satu kewajiban perpajakan sebagai Wajib Pajak yang baik dan Wajib Pajak yang patuh dengan demikian maka meningkatkan efektivitas pemrosesan data perpajakan yang dilakukan oleh Wajib Pajak Orang Pribadi, hal ini sejalan dengan penelitian yang dilakukan oleh Lingga (2012) dan Fasmi \& Misra (2013).

Semakin Modernisasi Perpajakan yang dilakukan oleh pemerintah semakin gencar dan tepat sasaran maka hal ini akan memudahkan Wajib Pajak Orang Pribadi di dalam melakukan pemrosesan data perpajakannya, sehingga pemrosesan data pajaknya akan semakin efektif.

\section{Simpulan dan Saran Simpulan}

Berdasarkan hasil penelitian dan pembahasan yang telah dilakukan dapat ditarik kesimpulan:

a) Efektivitas penerapan sistem e-filing yang dijalankan oleh pihak DJP yang dinilai oleh Wajib Pajak yang bekerja di Yayasan Bunda Mulia di dalam menjalankan kewajiban perpajakannya berpengaruh positif secara signifikan terhadap efektivitas pemrosesan data perpajakan. Efektifitas pemrosesan data perpajakan dipengaruhi oleh efektivitas penerapan sistem e-filing sebesar $24,0 \%$, sisanya $76,0 \%$ dipengaruhi oleh faktor-faktor lain yang tidak diamati dan diteliti pada penelitian ini.

b) Modernisasi Sistem Perpajakan Indonesia yang dijalankan dengan konsisten oleh Pihak DJP dimata persepsi seorang Wajib Pajak berpengaruh positif secara signifikan terhadap efektivitas pemrosesan data perpajakan. Efektifitas pemrosesan data perpajakan dipengaruhi oleh efektivitas penerapan sistem e-filing sebesar 13,3\%, sisanya $86,7 \%$ dipengaruhi oleh faktor-faktor lain yang tidak diamati dan diteliti pada penelitian ini.

\section{Saran}

Berdasarkan pembahasan dan kesimpulan yang didapat maka peneliti menyarankan beberapa hal yang diharapkan dapat membantu Pihak Pemerintah (DJP) dalam memberikan pelayanan dan pengawasan kepada wajib pajak. Saran yang diberikan sebagai berikut:

1. Karena masih banyak wajib pajak yang belum terbiasa dengan teknologi informasi maka seharusnya KPP memberi pelatihan terlebih dahulu kepada wajib pajak, khususnya pelaporan SPT dnegan sistem e-filing..

2. Diharapkan DJP meningkatkan kinerja sistem, sehingga dapat mengurangi terjadinya error pada sistem efiling ketika diakses oleh wajib pajak.

3. Mengadakan sosialisasi bahwa dengan e-filing wajib pajak akan sangat terbantu karena tidak perlu mengantri ke Kantor Pelayanan Pajak dan bisa dilakukan dimana saja dan kapan saja. Agar wajib pajak menggunakan e-filing dengan sukarela bukan karena diwajibkan oleh KPP, sehingga dapat meningkatkan efektivitas pemrosesan data perpajakan.

\section{Daftar Pustaka}

Ajzen, I. (2011). Theory of planned behavior: a bibliography. Retrieved September 29, 2011 from the World Wide Web: http://people.umass.edu/aizen/tp brefs.html.

Apriliani, I. (2014). Pengaruh Penerapan E-SPT (Masa PPN) Terhadap 
Efisiensi Pemrosesan Data Perpajakan (Studi Kasus Pada Pengusaha Kena Pajak di KPP Pratama Semarang Barat). EJurnal Pada UPT Perpustakaan Universitas Dian Nuswantoro Semarang, Hal. 1-12.

Asriningsih, K.D.J. \& Noviari, N. (2014). Pengaruh Penerapan E-SPT PPH Pasal 21 Pada Efisiensi Pemrosesan Data Perpajakan Bagi Wajib Pajak Badan. EJurnal Akuntansi Universitas Udayana. 8.3 (2014):493-508. ISSN: 2302-8556

Candra, Riski, Harris Wibisono, dan Mujilan. (2013). Modernisasi Sistem Administrasi Perpajakan Dan Kepatuhan Wajib Pajak. Jurnal Riset Manajemen dan Akuntansi, 1 (1).

Desmayanti, E. dan Zulaikha. 2012. "Faktor-faktor yang Mempengaruhi Penggunaan Fasilitas e-Filling oleh Wajib Pajak sebagai Sarana Penyampaian SPT Masa secara Online dan Realtime." Diponegoro Journal of Accounting Volume 1, no. 1. pp. $1-12$.

Direktorat Jenderal Pajak Kementrian Keuangan. "DJP dan PKP Siap Melaksanakan E-Faktur," http://www.pajak.go.id/content/a rticle/djp-dan-pkp-siapmelaksanakan-e-faktur, diakses tanggal 10 February 2017.

Direktorat Jenderal Pajak Kementrian Keuangan. "e-Faktur, Produk Mutakhir Pembenahan Administrasi Pajak," http://www.pajak.go.id/content/a rticle/e-faktur-produk-mutakhirpembenahan-administrasi-pajak, diakses tanggal 10 Februari 2017.

Direktorat Jenderal Pajak Kementrian Keuangan. "e-SPT," http://www.pajak.go.id/e-spt, diakses tanggal 10 Februari 2017.
Direktorat Jenderal Pajak Kementrian Keuangan. "Mudahnya Pelaporan Pajak melalui eFiling," http://www.pajak.go.id/content/ mudahnya-pelaporan-pajakmelalui-e-filing-0, diakses tanggal 10 Februari 2017.

Direktorat Jenderal Pajak Kementrian Keuangan. "Pendaftaran NPWP Online (e-Registration)," http://www.pajak.go.id/content/p endaftaran-npwp-onlineeregistration, diakses tanggal 10 Februari 2017.

Direktorat Jenderal Pajak Kementrian Keuangan. "Sistem Pembayaran Pajak Secara Elektronik (Billing System)," http://www.pajak.go.id/content/b illing-system, diakses tanggal 10 Februari 2017.

Ersania, G.A.R. \& Merkusiwati, N.K.L.A. (2018). Pengaruh Penerapan E-System Perpajakan Terhadap Tingkat Kepatuhan Wajib Pajak Orang Pribadi. EJurnal Akuntansi Universitas Udayana. Vol.22, No.3. Hal.1882-1908. ISSN: 23028556.

Fasmi, L. dan Misra, F. 2012 "Pengaruh Modernisasi Sistem Administrasi Perpajakan Terhadap Tingkat Kepatuhan Pengusaha Kena Pajak di Kantor Pelayanan Pajak (KPP) Pratama Padang." Jurnal Simposium Nasional Akuntansi 15.

Hartono, J. (2013). Metodologi Penelitian Bisnis: Salah Kaprah dan Pengalaman-Pengalaman. Edisi 6. Yogyakarta: Fakultas Ekonomika dan Bisnis UGM.

Laihad, Risal C. Y. 2013. "Pengaruh Perilaku Wajib Pajak terhadap Penggunaan e-Filling Wajib Pajak di Kota Manado." Jurnal $E M B A$, volume 1, no.3. pp. 4451

Lingga, I. S. 2012. "Pengaruh Penerapan $e-S P T \quad$ Terhadap Efisiensi 
Pemrosesan Data Perpajakan." Jurnal Akuntansi Universitas Kristen Maranatha. Volume 4 Nomor 2. pp. 101-114

Lie, Ivana dan Sadjiarto, A. 2013. Faktor-Faktor yang Mempengaruhi Perilaku Wajib Pajak untuk menggunakan $e$ filing. Tax and Accounting Review Journal, Vol 3, No.2.

"Peraturan Direktur Jenderal Pajak Nomor 47/PJ/2008 tanggal 16 Desember 2008 tentang Tata Cara Penyampaian Surat Pemberitahuan Secara Elektronik (e-Filling) Melalui Perusahaan Penyedia Jasa Aplikasi (ASP)." http://ortax.org/ortax/?mod=atura n\&page $=$ show\&id $=13534$, diakses tanggal 5 Oktober 2015.

"Peraturan Direktur Jenderal Pajak Nomor KEP - 05/PJ/2005 tanggal 12 Januari 2005 tentang Tata Cara Penyampaian Surat Pemberitahuan Secara Elektronik (e-Filling) Melalui Perusahaan Penyedia Jasa Aplikasi (ASP)." http://ortax.org/ortax/?mod=atura n\&page $=$ show \&id $=9334$, diakses tanggal 3 Oktober 2015.

"Peraturan Direktur Jenderal Pajak Nomor PER - 16/PJ/2014 tanggal 20 Juni 2014 tentang Tata Cara Pembuatan dan Pelaporan Faktur Pajak Berbentuk

Elektronik."http://www.ortax.org /ortax/?mod=aturan\&page $=$ show $7 \mathrm{id}=15537$, diakses tanggal 3 Oktober 2015.

Pratami, Sulindawati, dan Wahyuni. (2017). Pengaruh Penerapan ESystem Perpajakan Terhadap Tingkat Kepatuhan Wajib Pajak Orang Pribadi Dalam Membayar Pajak Pada Kantor Pelayanan Pajak (KPP) Pratama Singaraja. Journal Universitas Pendidikan Ganesha, Vol.7 No.1, Hal.1-15.

Priyatno, Duwi. (2016). SPSS Handbook: Analisis Data, Olah Data, \&
Penyelesaian Kasus-Kasus

Statistik. Jakarta: PT Buku Seru.

Rahayu, S. dan Lingga, I.S. 2009.

Pengaruh Modernisasi Sistem

Administrasi Perpajakan

terhadap Kepatuhan Wajib Pajak

Badan pada KPP Pratama

Bandung. Jurnal Akuntansi.

Volume. 1, No. 2: pp. 119-138

Richardson, G. 2006, Determinants of tax

evasion: A cross-country

investigation, Journal of

International Accounting,

Auditing and Taxation, 15, p.150-

169.

Rusli, Y. M. 2012. The Influence of Tax Payer's Awareness, Tax Service, and Tax Morale Against Tax Payment and Tax Evasion, study in Bandung city. Thesis, Universitas Kristen Maranahta, Bandung.

Ita Salsalina Lingga, I.S. (2012). Pengaruh Penerapan e-SPT Terhadap Efisiensi Pemrosesan Data Perpajakan: Survey Terhadap Pengusaha Kena Pajak pada KPP Pratama X, Bandung. Jurnal Akuntansi Vol.4 No.2, Hal.101-114.

Slemrod, Joel B and Marsha Blumenthal. 1996. The Income Tax Compliance Cost of Big Business. Public Finance Quarterly, Vol. 24, No. 14, October 2006.

Sugiyono (2015). Statistika untuk Penelitian. Bandung: Alfabeta.

Suharyadi, \& Purwanto. S. K. (2011). Statistika: Untuk Ekonomi dan Keuangan Modern. Jakarta: Salemba Empat.

Suharyadi, \& Purwanto. S. K. (2015). Statistika: Untuk Ekonomi dan Keuangan Modern. Edisi 2. Buku 2. Jakarta: Salemba Empat.

Suherman, M. \& Almunawwaroh, M. (2015). Pengaruh Penerapan EFiling Terhadap Kepatuhan Wajib Pajak Dalam Penyampaian Surat Pemberitahuan (SPT) Tahunan Pada Kantor Pelayanan 
Pajak Pratama Kota Tasikmalaya. Media Riset Akuntansi, Auditing \& Informasi, Vol. 15 No. 1, Hal. 99-115

Sujarweni, V.W. (2014). Metodologi Penelitian: Lengkap, Praktis, dan Mudah Dipahami. Yogyakarta: Pustaka Baru Press.

Suryabrata, S. (2014). Metodologi Penelitian. Jakarta: Rajawali Pers.

Torgler, B. and Schenaider, F. 2007. The Impact of Tax Morale and Institutional Quality on the Shadow Economy Journal, IZA DP No 2541

Torgler, B., Schaffner, M. and Schategger,C.A. 2003, Is Forgiveness Divine? A Cross-
Culture Comparison of Tax Amnesties, Swiss Journal of Economics and Statistics, 139(3): 375-396.

Undang-Undang Republik Indonesia Nomor 6 tahun 2009 tentang Ketentuan Umum dan Tata Cara Perpajakan.

Waluyo. Perpajakan Indonesia. Edisi ketiga. Buku satu. Jakarta : Salemba Empat, 2015.

Wibisona, L.T dan Toly, A. A. 2014. Analisis Faktor-Faktor yang Mempengaruhi Minat Wajib Pajak dalam menggunakan efiling di Surabaya. Tax and Accounting Review Journal, Vol 4, No.1. 